\title{
'NO GERMAN, NO LOVE': LANGUAGE PROFICIENCY AS A CONDITION FOR VISAS OF TURKISH SPOUSES UNDER EU LAW*
}

\author{
Nanette NEUWAHL ${ }^{* *}$
}

\begin{abstract}
In this article, the author argues that the Ankara Agreement and its 1970 Additional Protocol, as well as Association Council Decision 1/80 can be used to set aside new German visa restrictions which would make family reunification of immigrants conditional on the passing of a language or integration test. The opportunity to establish this comes after questions to this effect have been raised by the Administrative Court of Berlin in requests for preliminary rulings Under Article 267 TFEU. After Case C-513/12, Aslihan Nazli Ayalti v. Federal Republic of Germany was withdrawn from the register, Case C-138/13, Naime Dogan v. Federal Republic of Germany still constitutes an opportunity for the Court of Justice to underline once more the importance of the Ankara Agreement in the relations between the European Union and Turkey.
\end{abstract}

Keywords: EU, Ankara Agreement, Standstill Clause, Language Tests, Nondiscrimination, Family Reunification

\section{"ALMANCA YOKSA ASSK DA YOK" \\ AVRUPA BİRLIĞİ HUKUKU UYARINCA TÜRK EŞLERİN VIZZE İÇIN DİL YETERLİLIK KOŞULU}

\section{$\ddot{O}_{z e t}$}

Bu makalede yazar, Ankara Anlaşması ve onun 1970 tarihli Katma Protokolü ile 1/80 sayılı Ortaklık Konseyi Kararı'nın, göçmenlerin aile birleşimini dil ya da bütünleşme testinin geçilmesine bağlayan yeni Avrupa kısıtlamalarının iptal amacıyla ileri sürülebileceğini iddia ediyor. Buna ilişkin imkân, Berlin İdare Mahkemesi'nce, ABİ̈A madde 267 uyarınca ortaya atılan ön karar müracaatından ileri gelmektedir. Ayaltı davası çerçevesinde başvurulan ön karar prosedürünün

\footnotetext{
* I would like to thank Dr. Rolf Gutmann, Lawyer in Stuttgart, for his comment on an earlier draft of this article. I am solely answerable for the ideas expressed.

** Jean Monnet Professor of EU Law, Université de Montréal and Director of Studies, College of Europe, e-mail: nanette.neuwahl@umontreal.ca
} 
geri çekilmesi üzerine, Doğan davası, ABAD'ın AB ile Türkiye ilişkilerinde Ankara Antlaşmasının önemini vurgulaması açısından bir firsat olarak devam etmektedir.

Anahtar Kelimeler: AB, Ankara Antlaşması, Mevcudun Korunması Kurall, Dil Testleri, Ayrım Yapmama, Aile Birleşimi

\section{Introduction}

Several EU Member States require foreigners who want to reside in their country to pass language tests, ${ }^{1}$ sometimes combined with integration tests. Such tests act as a disincentive for third country nationals to settle there, and possibly as a barrier to migration into the European Union ${ }^{2}$ as a whole. Even so, these tests are in principle justifiable in terms of the public good. Language training in particular can serve a number of objectives ranging from the boosting of the identity of a nation, the protection of minorities, integration, civil protection, reasonable accommodation.

The matter is sensitive in the context of the EU. The EU has neither a harmonized immigration policy nor a harmonised language policy, but its primary law provides directly effective rights, in particular, for EU citizens who are lawfully resident in a Member State other than their own, and this entails a pressure on the policies of its Member States. EU citizens have a right to reside in a Member State other than their own conform the Treaty on the Functioning of the European Union (TFEU). While a Member State can subject the exercise of certain jobs to a language requirement, they can do so only because of a derogation in the TFEU. For example, EU trained doctors can be required to undergo a language test before being allowed to practice in as far as this was in the interest of patients. ${ }^{3}$ Although the tests are a restriction on the freedom of movement, they can be justified in the

\footnotetext{
${ }^{1}$ Cf. R. Van Oers, E. Ersboll and D. Kostakopoulou, A Re-definition of Belonging ? Language and Integration Test in Europe. Martinus Nijhoff Publishers 2010; Y. Pascouau, in collaboration with H. Labayle, Conditions for Family Reunification under Strain - A Comparative Study in Nine EU Member States. European Policy Centre, November 2011, pp. 88-94; C. Carlitz, 'Language Skills as a Requirement for Family Reunification of Spouses in Germany : Respecting Respect for Family Life ?', in : S. Morano-Foad and M. Malena, Integration for Third-Country Nationals in the European Union. The Equality Challenge. Edgar Elgar Publishing, 2012, pp. 303-23. See also G. Hogan-Brun, C. MarMolinero, P. Stevenson (eds.), Discourses on Language and Integration: Critical Perspectives on Language Testing Regimes in Europe. John Benjamins, Amsterdam 2009..

${ }^{2}$ The European Union (hereinafter : EU) is composed of 28 Member States : Austria, Belgium, Bulgaria, Croatia, Cyprus, Czech Republic, Denmark, Estonia, Finland, France, Germany, Greece, Hungary, Ireland, Italy, Latvia, Lithuania, Luxembourg, Malta, the Netherlands, Poland, Portugal, Romania, Slovakia, Slovenia, Spain, Sweden, United Kingdom.

${ }^{3}$ S. Borland, 'Doctors from the EU to Face Language Tests following Landmark Ruling', internet resource at http://www.dailymail.co.uk/health/article-2076367/Doctors-EU-face-language-testsfollowing-landmark-ruling.html (last visited 13 January 2014).
} 
public interest if they are proportional. ${ }^{4}$ Language requirements cannot be imposed in a blanket fashion on EU citizens who lawfully move within the EU.

The situation of third country nationals is far less clear, with the possible exception of spouses of EU nationals that move within the EU under the Citizen's Directive. ${ }^{5}$ Could passing a language test systematically be required from a third country spouse as a condition of residence when he or she wants to join an EU citizen who moves to another country? An effective interpretation of the Citizens' Directive, article 24(1) would suggest that it cannot. ${ }^{6}$ We shall come back to this later on. On a general level, however, it is most often assumed that Member States have retained the power to regulate immigration into their territory from outside the EU. Also, it is widely assumed that the 'social charter' constituted by the European Union treaties, first and foremost grants rights to EU citizens and members of their family of whatever nationality. The EU institutions can however grant rights to some categories of third country individuals independently of any link to an EU citizen, for instance by international agreement or by secondary EU legislation, and general principles of law and the Charter of the European Union on fundamental rights protect all citizens against abuse of power by the Union or by its Member States when acting in the implementation of EU law.

Today, the proliferation of EU legislation and the progressive refinement of EU law through jurisprudence exercise pressure on the law regarding third country nationals. This can be illustrated at the example of two recent requests for preliminary rulings submitted to the European Court of Justice by the Administrative Court of Berlin in connection with a practice whereby immigration to Germany was made contingent on passing a language test before entry onto the territory. ${ }^{7}$

\footnotetext{
${ }^{4}$ Case 379/87, Judgment of 28 November 1989, Groener v. Minister for Education and City of Dublin Vocational Education Committee, European Court Reports 1989, p. 3967. Case C-424/97, Judgment of 4 July 2000, Salomone Haim v. Kassenzahnärztliche Vereinigung Nordrhein, European Court Reports 2000, p. I-5123, operative part 3 of the judgment.

${ }^{5}$ Directive 2004/38/EC of the European Parliament and of the Council of 29 April 2004 on the right of citizens of the Union and their family members to move and reside freely within the territory of the Member States amending Regulation (EEC) No 1612/68 and repealing Directives 64/221/EEC, 68/360/EEC, 72/194/EEC, 73/148/EEC, 75/34/EEC, 75/35/EEC, 90/364/EEC, 90/365/EEC and 93/96/EEC (OJ 2004 L 158, p. 77, and corrigenda OJ 2004 L 229, p. 35 and OJ 2005 L 197, p. 34).

${ }^{6}$ Cf. Case C-127/08, Judgment of 25 July 2008, Metock and others v. Minister for Justice, Equality and Law Reform, European Court Reports 2008, p. I-6241.

${ }^{7}$ Decision of 25 October 2012, Verwaltungsgericht Berlin, VG 29 K 13812 V. Case C-513/12: Request for a preliminary ruling from the Verwaltungsgericht Berlin (Germany), lodged on 13 November 2012 - Aslihan Nazli Ayalti v. Federal Republic of Germany, Official Journal C63 of 2 March 2013, p. 6-8. This case was withdrawn by decision (Beschluss) of 8 March 2013 revoking the decision of 25 to request a preliminary ruling is revoked (aufgehoben) when the claimant in the main proceedings was able to prove sufficient language skills and the need for a preliminary ruling no longer existed in this case.
} 


\section{The Context of the Reference}

The facts of the first case are rather straightforward: The complainant in the first case, Mrs. Ayalti, was the wife of a Turkish worker in possession of a permanent residence permit in Germany. After the marriage took place in Turkey the woman applied for an entry visa to Germany for the purpose of family reunification, which was refused by the German embassy in Ankara on the grounds that the woman could not prove that she possessed, before immigration, the basic German language skills required since 2007 for immigration as a spouse. The woman appealed against this decision to the Verwaltungsgericht (administrative court) of Berlin, who then referred questions to the European Court of Justice. The request for a preliminary ruling was revoked when Mrs Ayalti passed the language test.

The circumstances of the second case are very similar, with the exception that Mr. Dogan is a self-employed immigrant and his wife, the applicant, is analphabetic is analphabetic and unable to pass the written part of the test.

It is to be noted that for the German authorities, the applicable law is first of all the German immigration law. A German judge will refer to EU law only if the German law is unclear or if there could be a conflict with EU primary or secondary law, including international agreements to which the EU is a party. In order to assist him, he may refer to the European Court of Justice under Article 267 TFEU, and this is what happened.

The Berlin Verwaltungsgericht referred the following questions to the Court of Justice of the European Union, identical in both cases:

1. Do Article 41(1) of the Additional Protocol of 23 November 1970 to the Agreement of 12 September 1963 establishing an Association between the European Economic Community and Turkey for the transitional stage of the Association (AP) and/or Article 13 of Decision No 1/80 of the EEC-Turkey Association Council of 19 September 1980 (Decision No 1/80) preclude a provision of national law which was introduced for the first time after the abovementioned provisions had come into force and which makes the first entry of a member of the family of a Turkish national who enjoys the legal status under Article 6 of Decision No 1/80 conditional on the requirement that, prior to entry, the family member can demonstrate the ability to make himself or herself understood, in a basic way, in the German language?

2. If the first question is to be answered in the negative: does the first subparagraph of Article 7(2) of Council Directive 2003/86/EC of 22 September 2003 on the right

However, a similar case referred by the same court is still pending : Decision of 23 February 2012, Verwaltungsgericht Berlin, VG $23 \mathrm{~K} 91.12 \mathrm{~V}$. Case C-138/13: Request for a preliminary ruling from the Verwaltungsgericht Berlin (Germany), lodged on 19 March 2013 - Naime Dogan v. Federal Republic of Germany, Official Journal C171 of 15 June 2013, p. 14-5. 
to family reunification [1] preclude the provision of national law mentioned in Question 1?

\subsection{German Law Provisions on Language Requirements for Spouses of Foreign Immigrants}

Under German law the obtention of the visa is governed by the following rules contained in the Federal Residence Act $^{8}$ (FRA):

Section 4 requires a visa for residence by foreigners, unless it it is determined otherwise, notably by decree or by EU law or on the basis of the Association Agreement with Turkey. ${ }^{9}$

$\S 4$ Erfordernis eines Aufenthaltstitels

(1) Ausländer bedürfen für die Einreise und den Aufenthalt im Bundesgebiet eines Aufenthaltstitels, sofern nicht durch Recht der Europäischen Union oder durch Rechtsverordnung etwas anderes bestimmt ist oder auf Grund des Abkommens vom 12. September 1963 zur Gründung einer Assoziation zwischen der Europäischen Wirtschaftsgemeinschaft und der Türkei (BGBl. 1964 II S. 509) (Assoziationsabkommen EWG/Türkei) ein Aufenthaltsrecht besteht. Die Aufenthaltstitel werden erteilt als

1. Visum im Sinne des $\S 6$ Absatz 1 Nummer 1 und Absatz 3, $[\ldots]$

Section 6 of the FRA requires for longer term residence a federal visa that is awarded before entry onto federal territory. ${ }^{10}$

\footnotetext{
${ }^{8}$ Gesetz über den Aufenthalt, die Erwerbstätigkeit und die Integration von Ausländern im Bundesgebiet (Aufenthaltsgesetz - AufenthG), neugefasst durch Bekanntmachung vom 25. Februar 2008 (BGBl. I S. 162), zuletzt geändert durch Art. 1 und Art. 6 Abs. 2 des Gesetzes vom 1. Juni 2012 (BGB1. I S. 1224).

${ }^{9}$ Translation into English by the author:

Requirement of a title of residence

(1) Foreigners need a title of residence in order to enter or stay in the territory of the Federation, unless something else is provides by European Union law or by regulation, or unless a right of residence exists by virtue of the Agreement of 12 September 1963 establishing an Association between the European Economic Community and Turkey [...]

The title of residence will be issued as

1. Visa in the sense of Section 6 [...]

${ }^{10}$ Translation into English by the author:

Section 6 Visa

$[\ldots]$

(3) Longer term residence requires a Visa for federal territory (national visa), which shall be issued before entrance. This will be issued in accordance with the Community regulations regarding residence permits, the EU blue card, the right of establishment and the long-term residence permit [...]
} 
$\S 6$ Visum

[...]

(3) Für längerfristige Aufenthalte ist ein Visum für das Bundesgebiet (nationales Visum) erforderlich, das vor der Einreise erteilt wird. Die Erteilung richtet sich nach den für die Aufenthaltserlaubnis, die Blaue Karte EU, die Niederlassungserlaubnis und die Erlaubnis zum Daueraufenthalt-EG geltenden Vorschriften. [...]

Section 27 FRA contains a principle of family reunification in Germany, in the interest of the protection of the couple and the family in accordance with Article 6 of the Basic Law. ${ }^{11}$

\section{$\S 27$ Grundsatz des Familiennachzugs}

(1) Die Aufenthaltserlaubnis zur Herstellung und Wahrung der familiären Lebensgemeinschaft im Bundesgebiet für ausländische Familienangehörige (Familiennachzug) wird zum Schutz von Ehe und Familie gemäß Artikel 6 des Grundgesetzes erteilt und verlängert.

$[\ldots]$

Section 30 FRA gives the wife or husband of a foreigner who has a right of residence the right to join the spouse if certain conditions are fulfilled, including the requirement that he or she is able to express him or herself at least in a simple way in the German language. The latter requirement is laid down in the second sentence of the first subsection of Section 30 and, according to subsections 2 and 3 , is not applicable in all cases : it is not applicable to all foreigners (subsection 2) and not applicable if the spouse is ill or incapable (subsection 3 ). ${ }^{12}$

\footnotetext{
${ }^{11}$ Translation into English by the author: Section 27 Principle of family reunification

(1) The residence permit for the purpose of constituting and securing the family unit of foreign members of the family in the territory of the Federation (family reunification) will $b$ issued and prolonged for the protection of the marriage and family in accordance with Article 6 of the Basic Law.

$[\ldots]$

${ }^{12}$ Translation into English by the author:

Section 30 Spousal reunification

(1) The spouse of a foreigner shall be issued with a residence permit when

1. both spouses have accomplished their $18^{\text {th }}$ year of life.

2. the spouse can express him/herself at least in a simple way in German and

3. the foreigner

a. is in possession of a permit of establishment [...]

(2) Subsection $1 \mathrm{Nr} .2$ is irrelevant for the issuance of a residence permit when

1. the foreigner is in possession of a residence permit in accordance with sections 19-21 [for certain professional activities] and the marriage existed already at the moment when that foreigner moved his main life perspective to the territory of the federation [...]
}

(3) Subsection 3 is irrelevant for the issuance of a residence permit when 


\section{$\S 30$ Ehegattennachzug}

(1) Dem Ehegatten eines Ausländers ist eine Aufenthaltserlaubnis zu erteilen, wenn

1. beide Ehegatten das 18. Lebensjahr vollendet haben

2. der Ehegatte sich zumindest auf einfache Art in deutscher Sprache verständigen kann und

3. der Ausländer

a) eine Niederlassungserlaubnis besitzt, [...]

(2) Satz 1 Nr. 2 ist für die Erteilung der Aufenthaltserlaubnis unbeachtlich, wenn

1. der Ausländer einen Aufenthaltstitel nach den $\S \S 19$ bis 21 [für bestimmte

Erwerbstätigkeiten] besitzt und die Ehe bereits bestand, als er seinen Lebensmittelpunkt in das Bundesgebiet verlegt hat [...]

(3) Satz 1 Nr. 2 ist für die Erteilung der Aufenthaltserlaubnis unbeachtlich, wenn

1. $[\ldots]$

2. der Ehegatte wegen einer körperlichen, geistigen oder seelischen Krankheit oder Behinderung nicht in der Lage ist, einfache Kenntnisse der deutschen Sprache nachzuweisen, [...]

Thus, it appears that unless she was dispensed from the visa requirement, the complainant in the case before the Administrative Court needed to obtain a visa before entry, which she would obtain if she could prove either the possession of adequate language skills or the application of an exception based on illness or disability.

The provisions of the FRA on the requirement of language skills as a criterion for the issuing of a visa are not applicable to European Union nationals ${ }^{13}$ or their third country spouses. ${ }^{14}$ They were inserted by a 2007 law for the transposition of certain EU directives on residence and asylum. ${ }^{15}$ This was a new device. Neither the original version of the Residence Act of $2004^{16}$, nor the Aliens Act $1990^{17}$ or 1965 had previously contained a similar disposition. The reason why it was introduced by the federal government was explained as follows : ${ }^{18}$ Article 7 paragraph 2 of the EU family reunification directive provides for the possibility of making family reunification of third country nationals covered by that directive dependent on the

$1[\ldots]$ the spouse is not able to prove simple notions of German because of physical, mental or emotional illness or disability, [...]

${ }^{13}$ Cf. The German Federal Act on the free movement for EU citizens : Gesetz über die allgemeine Freizügigkeit von Unionsbürgern, FreizügG/EU vom 30. Juli 2004, BGBl. I S 1950, zuletzt geändert durch Gesetz vom 20. Dezember 2011.

${ }^{14}$ Section 2 subsection $4,2^{\mathrm{e}}$ of the Federal Act on the free movement for EU citizens and Section 11 of the RFA on the application of the FRA.

${ }^{15}$ Gesetz zur Umsetzung aufenthalts- und asylrechtlicher Richtlinien der Europäischen Union vom 19. August 2007 (BGBl. I S. 1970), Art. 1, paragraph 22, lit. a.

${ }^{16}$ Cf. Aufenthaltsgesetz of 30. Juli 2004 (BGBl. I S. 1950).

${ }^{17}$ Cf. Ausländergesetz of 28. April 1965 (BGB1. I S. 353).

${ }^{18}$ BTDrucks. 16/5065 S. 173. 
fulfilment of integration measures. The new rule will motivate the persons concerned to acquire simple German language notions before immigration and thus facilitate their integration. Language proficiency, even of a basic level is an effective way to empower potential victims of oppression: in particular, the government has found that in-laws of victims of forced marriages purposefully or indirectly exploit a lack of language skills and prevent the victims from having an independent social life. The mere obligation to take part in language classes, says the government, does not remedy the lack of an independent social life, only the successful completion will be able to achieve this result. The obligation to prove language skills before immigration guarantees effectively that the basic language notions are available. The mere participation in a language class does not imply a successful completion. A pre-entry language test has much more preventive effect than a post-entry test when the victim may continue to be subject to pressure from the in-laws. Educated men and women are less attractive targets for those who practice these habits, because they are less easily controllable. Even simple language notions suffice in this respect. The Federal Ministry of the Interior considers that the requirement to be able to express oneself at least in rudimentary German corresponds to Language level A 1 of the Common European Framework of Reference which the Council of Europe adopts for languages.

The German Federal Government furthermore held the position that the new disposition did not represent an unreasonable burden and was the least onerous, as well as weighing adequately the protected public goods : freedom to marry and to choose one's future, and indirectly, sexual self-determination and integrity of the body. ${ }^{19}$ In its recent comments on the European Commission's Green Paper on the right to family reunification of third-country nationals living in the European Union, the Federal Government of Germany also refers to the availability of a hardship case provision in German law applying to sick and disabled persons and the existence of a broad range of language courses and options for taking a language proficiency test offered abroad (mainly by the Goethe Institutes) which ensure that the requirement to demonstrate a basic language proficiency is no unreasonable barrier to family reunification ${ }^{20}$ :

So as to compensate for hardships as required by the constitution, a temporary residence permit for language acquisition purposes may be granted in line with Section 16, subsection 5 of the Residence Act if the spouse wishing to immigrate subsequently cannot acquire the basic language skills for reasons beyond her control and if, at the same time, the spouse living in Germany is unable to establish marital cohabitation outside the federal territory for objective factual or legal

\footnotetext{
${ }^{19}$ BT-Drucks. 16/5065, p. 173.

${ }^{20}$ Nr. 30.1.2.1. der Allgemeinen Verwaltungsvorschrift des Bundesministeriums des Innern zum Aufenthaltsgesetz vom 26. Oktober 2009 (GMB1 S. 878) - VV AufenthG.
} 
reasons, or if he or she cannot be expected to do so owing to particular circumstances. $^{21}$

The legality of the language condition has never been called into question by German courts ; until a communication from the Commission (to which we shall return) cast doubt on the matter. On the contrary. The Federal Administrative Court had expressly discarded the possibility of incompatibility with Article 41(11) of the Additional Protocol to the Ankara Agreement, with Article 13 of Decision 1/80 of the Association Council and with Article 7(2) of the EU Directive on family reunification. $^{22}$ In its judgment of 25 March 2011 the Federal Constitutional Court, while deciding that the decision of the Federal Administrative Court did not violate the German basic law ${ }^{23}$ did not comment on the compatibility or otherwise with European Union Law. However, after becoming aware of a position paper ${ }^{24}$ of the European Commission on the interpretation of Article 7(2) of the EU Directive on family reunification submitted to the Court by the European Commission in the Imran case (Case C-155/11 PPU), the Federal Administrative Court ${ }^{25}$ held that the question of the compatibility of the requirement of basic German proficiency should have been referred to the European Court of Justice. The Court could not clarify the matter in that case because in the meantime (because the status of the person concerned had changed and the directive no longer applied to him) the question had become without an object and it had to be decided only on the costs.

Interestingly, the Federal Administrative Court has subsequently decided in the case of a spousal reunification of a German national, that an interpretation in conformity with the federal Basic Law required that the condition could not be imposed before immigration if efforts were too onerous or not successful within a year. ${ }^{26}$ By virtue of a provision in Section 28 of the Federal Residence Act, ${ }^{27}$ the second point of the first sentence of subsection of Section 30 applies only " correspondingly ». As a result, it cannot be used to effectively deprive a German of his constitutional right of settlement in his own country. The Federal Administrative Court has noted that the criteria for spouses of Germans are to be treated differently because the fundamental right laid down in Article 11 of the Basic Law guaranteed the right of residence only to Germans and not to foreigners. (Marginal 25 et seq.). Moreover, European Union law was not applicable in the case at hand because the German citizen in question had not moved in the European Union (Marginal 11).

\footnotetext{
${ }^{21}$ COM doc 2011735 final, 15 November 2011.

${ }^{22}$ Bundesverwaltungsgericht, judgment of 30 March 2010 - 1 C 8.09 -, BVerwGE 136, 231.

${ }^{23}$ Bundesverfassungsgericht, decision of 25 March 2011 - 2 BvR 1413/11 -, NVwZ 2011, 870.

${ }^{24} \mathrm{Sj} . \mathrm{g}$ (2011) 540657, in the register of the Court of Justice under $\mathrm{Nr}$ 873.079.

${ }^{25}$ Decision of 28 October 2011, 1 C 9.10 , marginal 3.

${ }^{26}$ Bundesverwaltungsgericht, judgement of 4 September $2012-10$ C 12.12 .

${ }^{27}$ More precisely, the fifth sentence of the first subsection of Section 28.
} 
It is finally in its Decision of 25 October 2012 that the Administrative Court of Berlin refers the question to the European Court of Justice as to the compatibility of the language condition with the 1970 Additional Protocol ${ }^{28}$ to the Agreement Creating An Association Between The Republic of Turkey and the European Economic Community of 1963 ("Ankara Agreement"), ${ }^{29}$ Association Council Decision $1 / 80^{30}$ and the Council Directive on family reunification. ${ }^{31}$

\subsection{Main provisions of EU law of Relevance to the Question}

At the heart of the problem are two stand-still provisions : Article 41(1) of the Additional Protocol and Article 13 of Association Council Decision 1/80, as well as article 7 (2) $1^{\mathrm{e}}$ of Directive 2003/86 on family reunification which allows Member States to prescribe integration measures.

Article 41(1) of the Additional Protocol embodies a standstill clause which provides as follows:

1. The Contracting Parties shall refrain from introducing between themselves any new restrictions on the freedom of establishment and the freedom to provide services.

Article 13 of Association Council Decision 1/80 provides :

The Member States of the Community and Turkey may not introduce new restrictions on the conditions of access to employment applicable to workers and members of their families legally resident and employed in their respective territories.

These provisions need to be considered because the requirement of specific language proficiency evidence may constitute a new restriction on the economic freedoms mentioned therein. Whereas the meaning of both these clauses has progressively been clarified, the European Court of Justice has dealt with the notions of 'restrictions on the freedom of establishment and the freedom to provide services' and of 'restrictions on the conditions of to the access to employment' restrictively, in the sense of restrictions on the right to exercise an economic activity, largely in isolation from the right of family reunification. One could argue that this view is too restrictive and needs to be refined.

\footnotetext{
${ }^{28}$ This additional protocol was signed on 23 November 1970 at Brussels and concluded, approved and confirmed on behalf of the Community by Council Regulation (EEC) No 2760/72 of 19 December 1972 and is published in Official Journal 1973, C113, p. 18.

${ }^{29}$ Official Journal of the European Communities 1973, C113, p. 2.

${ }^{30}$ Decision 1/80 of the Association Council of 19 September 1980 on the Development of the Association. Text available at www.inis.gov.ie/en/.../DECISION...1_80.../DECISION_No_1_80_eng.pdf (last visited 13 January 2014.

${ }^{31}$ Council Directive 2003/86/EC of 22 September 2003 on the right to family reunification, OJ L 251, 3.10.2003, p. 12-18.
} 
Also at issue is article 7 (2) $1^{\mathrm{e}}$ of Directive 2003/86 on family reunification - a directive that applies to spouses of third country nationals residing in the EU who themselves have third country nationality. The article provides :

Member States may require third country nationals to comply with integration measures, in accordance with national law.

With regard to the refugees and/or family members of refugees referred to in Article 12 the integration measures referred to in the first subparagraph may only be applied once the persons concerned have been granted family reunification. '

The provision in the first sentence is ambiguous and the referring court has asked for its interpretation. Taken literally, it seems to allow Member States to ask spouses of foreign nationality to undertake language classes before immigrating. However, what is not clear is whether the Member State may make the successful conclusion of the language classes a condition for entry of the spouses of a third country national covered by the directive.

Article 7 needs to be seen also in the context of the objectives of the directive, which are clear from several recitals in the preamble but which do not lay down rights directly applicable for private individuals :

(2) Measures concerning family reunification should be adopted in conformity with the obligation to protect the family and respect family life enshrined in many instruments

of international law. This Directive respects the fundamental rights and observes the principles recognised in particular in Article 8 of the European Convention

for the Protection of Human Rights and Fundamental Freedoms and in the Charter of Fundamental Rights of the European Union.

(3) $[\ldots .$.$] European Union should ensure fair treatment of third country nationals$ residing lawfully on the territory of the Member States and that a more vigorous integration

policy should aim at granting them rights and obligations comparable to those of citizens of the European Union [.....]

(4) Family reunification is a necessary way of making family life possible. It helps to create socio-cultural stability facilitating the integration of third country nationals in the Member State, which also serves to promote economic and social cohesion, a cohesion, a fundamental Community objective stated in the Treaty.

(5) Member States should give effect to the provisions of this Directive without discrimination on the basis of sex, race, colour, ethnic or social origin, genetic characteristics, language, religion or beliefs, political or other opinions, 
membership of a national minority, fortune, birth, disabilities, age or sexual orientation.

(6) To protect the family and establish or preserve family life, the material conditions for exercising the right to family reunification should be determined on the basis

of common criteria.

(7) Member States should be able to apply this Directive also when the family enters together.

(9) Family reunification should apply in any case to members of the nuclear family, that is to say the spouse and the minor children.

(15) The integration of family members should be promoted. For that purpose, they should be granted a status independent of that of the sponsor, in particular in cases of breakup of marriages and partnerships, and access to education, employment and vocational training on the same terms as the person with whom they are reunited, under the relevant conditions.

(16) Since the objectives of the proposed action, namely the establishment of a right to family reunification for third country nationals to be exercised in accordance with common rules, cannot be sufficiently achieved by the Member States and can therefore, by reason of the scale and effects of the action, be better achieved by the Community, the Community may adopt measures, in accordance with the principle of subsidiarity as set out in Article 5 of the Treaty. In accordance with the principle of proportionality as set out in that Article, this Directive does not go beyond what is necessary in order to achieve those objectives.

Article 2 (d) of the directive provides that 'family reunification' means the entry into and residence in a Member State by family members of a third country national residing lawfully in that Member State in order to preserve the family unit, whether the family relationship arose before or after the resident's entry.

Furthermore, Article 3 of the Directive provides :

1. This Directive shall apply where the sponsor is holding a residence permit issued by a Member State for a period of validity of one year or more who has reasonable prospects of obtaining the right of permanent residence, if the members of his or her family are third country nationals of whatever status.

Article 4 stipulates :

1. The Member States shall authorise the entry and residence, pursuant to this Directive and subject to compliance with the conditions laid down in Chapter IV, as well as in Article 16, of the following family members: the sponsor's spouse; 
The provision of the Directive on which the Administrative Court needs clarification is more specifically contained in Chapter IV, entitled 'Requirements for the exercise of the right to family reunification', and is consequently among a range of specific 'requirements' in articles 6,7 and 8:

Article 6

1. The Member States may reject an application for entry and residence of family members on grounds of public policy, public security or public health.

2. Member States may withdraw or refuse to renew a family member's residence permit on grounds of public policy or public security or public health.

When taking the relevant decision, the Member State shall consider, besides Article $17,^{32}$ the severity or type of offence against public policy or public security committed by the family member, or the dangers that are emanating from such person.

$[\ldots .$.

Article 7

1. When the application for family reunification is submitted, the Member State concerned may require the person who has submitted the application to provide evidence that the sponsor has:

(a) accommodation regarded as normal for a comparable family in the same region and which meets the general health and safety standards in force in the Member State concerned;

(b) sickness insurance in respect of all risks normally covered for its own nationals in the Member State concerned for himself/herself and the members of his/her family;

(c) stable and regular resources which are sufficient to maintain himself/herself and the members of his/her family, without recourse to the social assistance system of the Member State concerned. Member States shall evaluate these resources by reference to their nature and regularity and may take into account the level of minimum national wages and pensions as well as the number of family members.

${ }^{32}$ Article 17 provides : Member States shall take due account of the nature and solidity of the person's family relationships and the duration of his residence in the Member State and of the existence of family, cultural and social ties with his/her country of origin where they reject an application, withdraw or refuse to renew a residence permit or decide to order the removal of the sponsor or members of his family. 
2. Member States may require third country nationals to comply with integration measures, in accordance with national law.

With regard to the refugees and/or family members of refugees referred to in Article 12 the integration measures referred to in the first subparagraph may only be applied once the persons concerned have been granted family reunification.

Article 8

Member States may require the sponsor to have stayed lawfully in their territory for a period not exceeding two years, before having his/her family members join him/her.

By way of derogation, where the legislation of a Member State relating to family reunification in force on the date of adoption of this Directive takes into account its reception capacity, the Member State may provide for a waiting period of no more than three years between submission of the application for family reunification and the issue of a residence permit to the family members.

Finally, article 16, which is contained in the chapter on 'penalties and redress' provides :

1. Member States may reject an application for entry and residence for the purpose of family reunification, or, if appropriate, withdraw or refuse to renew a family member's residence permit, in the following circumstances:

(a) where the conditions laid down by this Directive are not or are no longer satisfied.

When renewing the residence permit, where the sponsor has not sufficient resources without recourse to the social assistance system of the Member State, as referred to in Article 7(1)(c), the Member State shall take into account the contributions of the family members to the household income;

(b) where the sponsor and his/her family member(s) do not or no longer live in a real marital or family relationship;

(c) where it is found that the sponsor or the unmarried partner is married or is in a stable long-term relationship with another person.

2. Member States may also reject an application for entry and residence for the purpose of family reunification, or withdraw or refuse to renew the family member's residence permits, where it is shown that:

(a) false or misleading information, false or falsified documents were used, fraud was otherwise committed or other unlawful means were used;

(b) the marriage, partnership or adoption was contracted for the sole purpose of enabling the person concerned to enter or reside in a Member State. 
When making an assessment with respect to this point, Member States may have regard in particular to the fact that the marriage, partnership or adoption was contracted after the sponsor had been issued his/her residence permit.

3. The Member States may withdraw or refuse to renew the residence permit of a family member where the sponsor's residence comes to an end and the family member does not yet enjoy an autonomous right of residence under Article 15.

4. Member States may conduct specific checks and inspections where there is reason to suspect that there is fraud or a marriage, partnership or adoption of convenience as defined by paragraph 2 . Specific checks may also be undertaken on the occasion of the renewal of family members' residence permit.

\section{Analysis}

\subsection{The Relationship between German Law and EU Law}

It is common ground that German law needs to be applied as far as possible in a way that is consistent with EU law, including agreements to which the EU is a party. This explains the reference to the European Court of Justice. Asking for an interpretation of the relevant EU provisions enables the national court to assess the legality of the application of the national law, respectively, to chose an interpretation of a provision of national law that is open to interpretation in such a way as to be conform EU law. The reference is to be welcomed, as it perfectly corresponds to the national Court's duties of 'loyal cooperation' under article 4(3) TEU.

\subsection{The Meaning of the Stand-Still Clauses}

The Administrative Court would like to be able to assess whether the stand-still clause in the Additional Protocol excludes the introduction, for entry visa purposes, of new mandatory language tests for spouses of Turkish nationals residing in Germany in the context of the freedom of establishment and the freedom to provide services.

\subsubsection{The interpretation of Article 41(1) of the 1963 Additional Protocol to the Ankara Agreement}

Article 41(1) of the Additional Protocol provides as follows:

1. The Contracting Parties shall refrain from introducing between themselves any new restrictions on the freedom of establishment and the freedom to provide services. 
In the case Savaş, the European Court provided that Article 41 paragraph 1 of the Additional Protocol was directly applicable, ${ }^{33}$ in the sense that it was clear and precise enough for national courts to apply. Private individuals could therefore invoke the article in order to avoid the application of new restrictions to their freedom of establishment and their freedom to provide services after the entry into force of the Additional Protocol. For example, in the beginning of 1973, when the protocol came into effect, Turkish nationals were allowed to settle in the UK without restrictions, including self-employment, and so the couple Savaş continued to hold this right in 2000. Similarly, in the Netherlands there existed no visa requirements for self-employment by Turkish nationals and so, the stand-still provision applies. ${ }^{34}$ One may note that because the provision does not affect restrictive rules that were in place in any given Member State at the time of the entry into force of the Additional Protocol for the state concerned, rights of Turkish nationals are not uniform throughout the territory of the EU.

In Soysal the Court ruled: ${ }^{35}$

Article 41(1) of the Additional Protocol, [...] is to be interpreted as meaning that it precludes the introduction, as from the entry into force of that protocol, of a requirement that Turkish nationals such as the appellants in the main proceedings must have a visa to enter the territory of a Member State in order to provide services there on behalf of an undertaking established in Turkey, since, on that date, such a visa was not required.

On the basis of this judgment, any new German visa requirements for Turkish service providers, even if resulting from the implementation of Regulation $539 / 2001^{36}$ constitute restrictions for the freedom to provide services in Germany and need to be replaced by exemptions. As regards self-employed persons the Court moreover generously held in $O g u z^{37}$ that :

Article 41(1) of the Additional Protocol [...] must be interpreted as meaning that it may be relied on by a Turkish national who, having leave to remain in a Member State on condition that he does not engage in any business or profession, nevertheless enters into self-employment in breach of that condition and later applies to the national authorities for further leave to remain on the basis of the business which he has meanwhile established.

\footnotetext{
${ }^{33}$ Case C-37/98, Judgment of 11 May 2000, Savaş, European Court Reports 2000, p. I-2927, paragraphs 45-54.

${ }^{34}$ District Court of The Hague, judgment of 14 February 2011, case 10/6045.

${ }^{35}$ Case C-228/06, Judgment of 19 February 2009, Soysal and Savatli, European Court Reports 2009, p. I-1031, operative part of the judgment.

${ }^{36}$ Council Regulation (EC) No 539/2001 of 15 March 2001 listing the third countries whose nationals must be in possession of visas when crossing the external borders and those whose nationals are exempt from that requirement, OJ L 81, 21.3.2001, p. 1-7.

${ }^{37}$ Case C-186/10, Judgment of 21 July 2011, Oguz, not yet published. Operative part of the judgment.
} 
Article 41(1) is therefore a powerful tool for protecting the status quo as regards visa free travel for service providers in those countries where no restrictions existed before 1973. If no visa requirements were in place in a Member State at the entry into force of the Protocol, they may not be introduced for whatever reason. ${ }^{38}$

The Court has however also ruled that the adoption of new rules which apply equally to Turkish nationals and to nationals of EU Member States and that are administered evenhandedly in the sense that they are no disproportionate burden on the Turkish national are not inconsistent with any of the standstill clauses laid down in the fields covered by the Ankara Agreement : ${ }^{39}$

The adoption of measures which apply in the same way to both Turkish nationals and citizens of the Union is not inconsistent with the standstill rules. If such measures applied to nationals of Member States but were not also imposed on Turkish nationals, Turkish nationals would be placed in a more favourable position than citizens of the Union, which would be clearly contrary to the requirement laid down in Article 59 of the Additional Protocol, under which the Republic of Turkey may not receive more favourable treatment than that which Member States grant to one another pursuant to the EC Treaty (see, to that effect, Soysal and Savatli, paragraph 61, and Sahin, paragraph 67).

In the case under consideration, however, we are not concerned with measures that apply to EU nationals.

Hitherto, the Court of Justice has not yet interpreted Article 41(1) as including the right to family reunification of Turkish couples, or as giving a right to visa-free residence, even if Soysal has increased pressures on the courts. ${ }^{40}$ It has been argued that Soysal could be used to obtain the exemption of visas for Turkish tourists and other consumers of services where they were not previously required to obtain a visa - since In EU law, the reception of services is considered a necessary corollary of the provision of services. ${ }^{41}$ This line of thinking was cut short by the Court in

\footnotetext{
${ }^{38}$ A rigorous conception of the stand-still clause would entail that not even the Association Council can allow any unilateral regression, because the Ankara Agreement is meant to progressively establish the approximation of the conditions of economic activity between the parties.

39 Case C-92/07, Judgment of 29 April 2010, Commission v. The Netherlands, European Court Reports 2010, p. I3683, paragraph 62.

${ }^{40}$ V. Polat, 'L'accord d'Ankara et la libre prestation des services. De l'effectivité de la clause de standstill', in : B. Bonnet (ed.), Turquie et Union Européenne. État des lieux, Bruylant, Bruxelles 2012, pp. 229-242, at p. 242.

41 E.g., Joined cases 286/82 and 26/83, Judgment of 31 January 1984, Graziana Luisi and Giuseppe Carbone v. Ministero del Tesoro, European Court Reports 1984, page 37; Case 186/87, Judgment of 2 February 1989, Ian William Cowan v. Trésor public, European Court Reports 1989, p. 195; Case C159/90, Judgment of 4 October 1991, The Society for the Protection of Unborn Children Ireland Ltd v. Stephen Grogan and others, European Court Reports 1991, p. I-4685.
} 
Demirkan, when it held that this matter is not covered by Article 41(1). ${ }^{42}$ Demirkan must, however, be distinguished from the case under consideration, which falls squarely in the line of the accepted case law of the Court, to the effect that a notion contained in the Ankara Agreement or in an Association Council Decision needs to be understood by analogy to the interpretation of an identical provision in EU primary law or a provision of secondary law. ${ }^{43}$ Thus, the Court has held in an important judgment on rights of workers: ${ }^{44}$

55 When determining the scope of the public policy exception [provided for in Article 14(1) of Decision 1/80], reference should, according to settled case-law, be made to the interpretation given to that exception in the field of freedom of movement for workers who are nationals of a Member State of the European Union (see, inter alia, Polat, paragraph 30).

56 The Court has always emphasised that that exception is a derogation from the fundamental principle of freedom of movement for persons, which must be interpreted strictly, and that its scope cannot be determined unilaterally by the Member States (see, inter alia, Polat, paragraph 33 and the case-law cited).

58 Furthermore, measures taken on grounds of public policy or of public security are to be based exclusively on the personal conduct of the individual concerned. Such measures can thus not be ordered automatically on general preventive grounds following a criminal conviction (Polat, paragraphs 31 and 35).

60 It is therefore for the national authorities concerned to assess on a case-by-case basis the personal conduct of the offender and whether it constitutes a present, genuine and sufficiently serious threat to public policy and security, and those authorities are also required to observe both the principle of proportionality and the fundamental rights of the person concerned. In particular, a measure ordering expulsion based on Article 14(1) of Decision No 1/80 may be taken only if the personal conduct of the person concerned indicates a specific risk of new and serious prejudice to the requirements of public policy (see Derin, paragraph 74).

As regards the rights of people engaging in any business or profession to be accompanied or joined by a spouse, it comes naturally to compare the situation to the rights of the economically active who moves in the EU and whose spouse has the right to move with him or her. In relation to EU nationals who migrate within the European Union for work, establishment, or the provision of services, all EU

\footnotetext{
${ }^{42}$ Case C-221/11, Judgment of 24 September 2013, Leyla Ecem Demirkan v. Federal Republic of Germany, European Court Reports 2013, p. I-00000.

${ }^{43}$ E.g., Case C-1/97, Birden v. Bremen, European Court Reports 1998, p. I-7747; Case C-275/02, Ayaz v. Land Baden-Württemberg, European Court Reports 2004, p. I-8765; Case C-303/08, Land BadenWürttemberg v. Metin Bozkurt, European Court Reports 2010, p. I-13445.

${ }^{44}$ Case C-303/08, Judgment of 22 December 2010, Land Baden-Württemberg v. Metin Bozkurt, European Court Reports 2010, p. I-13445.
} 
institutions have recognised the right of such people to be accompanied by their immediate family, including a spouse of whatever nationality. This right is now codified in the Citizens' Directive. ${ }^{45}$ The right is in part based on an effective interpretation of the right of EU nationals to work anywhere in the European Union and corresponds to the consideration that EU nationals would not move across borders if they can be requested to leave their close family behind. One can easily understand that the same applies to Turkish nationals who may want to do the same: they are more ready to come to the EU, and Turkish companies will be more easily engaging in significant economic activity the more migration is liberalized.

Similarly, the Court held that the provision of the EC Treaty on the freedom to provide services, read in conjunction with the fundamental right to respect of family life, can preclude a refusal by the Member State of origin of a provider of services established in a Member State and providing services to recipients established in other Member States, of the right to reside in its territory to that provider's spouse who is a national of a third country. ${ }^{46}$

Nevertheless, as Christine Kaddous ${ }^{47}$ rightly remarks, concepts of EU law cannot always automatically be copied and pasted to the context of the Ankara Agreement because that law has to be interpreted according to is own specific objectives and it is of course always necessary to take into account all of the provisions of the agreement as well as the decisions of the Association Council to establish its own interpretative context. Ségolène Barbou Desplaces also stresses that whereas the objective of the Ankara Agreement is the approximation of the rights of Turkish citizens and EU citizens, the actual rights, rather than being similar, can be variations on a theme. ${ }^{48}$ Thus, in a recent judgment the Court has taken the position that the right of Turkish citizens under the Ankara Agreement can not be fully compared to those of citizens of the EU who move under Directive

\footnotetext{
${ }^{45}$ Directive 2004/38/EC of the European Parliament and of the Council of 29 April 2004 on the right of citizens of the Union and their family members to move and reside freely within the territory of the Member States amending Regulation (EEC) No 1612/68 and repealing Directives 64/221/EEC, 68/360/EEC, 72/194/EEC, 73/148/EEC, 75/34/EEC, 75/35/EEC, 90/364/EEC, 90/365/EEC and 93/96/EEC (OJ 2004 L 158, p. 77, and corrigenda OJ 2004 L 229, p. 35 and OJ 2005 L 197, p. 34).

${ }^{46}$ Case C-60/00, Judgment of 11 July 2002, Mary Carpenter v. Secretary of State for the Home Department, European Court Reports 2002, p. I-6279, operative part of the judgment.

${ }^{47}$ Chr. Kaddous, 'Le rôle de la Cour de Justice dans l'interprétation de l'accord d'Association CEETurquie', in : B. Bonnet (ed.), Turquie et Union Européenne. État des lieux, Bruylant, Bruxelles 2012, pp. $79-105$, at p. 99.

${ }^{48}$ S. Barbou des Places, 'La Cour de Justice et l'Accord d'Ankara : variations jurisprudentielles sur la vocation européenne des travailleurs turcs', in : B. Bonnet (ed.), Turquie et Union Européenne. État des lieux, Bruylant, Bruxelles 2012, pp. 199-228.
} 
2004/38. In the context of Article 14 of Association Council Decision 1/80 the Court has held: ${ }^{49}$

[Since] protection against expulsion conferred by that provision on Turkish nationals does not have the same scope as that conferred on citizens of the Union under Article 28(3)(a) of directive 2004/38 [...] the scheme of protection against expulsion enjoyed by the latter cannot be applied mutatis mutandis to Turkish nationals $[\ldots]$

It had already appeared from the Demirel case ${ }^{50}$ that a right to family reunification could not be based directly on the Ankara Agreement. The case concerned a Turkish woman whose husband had been working in Germany since 1979. In 1984 she applied for a visa wanting to join her husband for the purpose of family reunification. Because German Law since 1982 allowed family reunification of third country nationals only for workers who had spent eight years in Germany, she was able to obtain only a temporary visitor's permit, at the expiry of which in 1985 she was issued with an expulsion order. The Administrative Court in Stuttgart who had to judge her appeal against the order referred the matter to the European Court of Justice for decision. The Court of Justice, while establishing that it had the power to interpret the relevant provisions (since the Ankara Agreement was part of Community law), expressly denied their direct effect. In the Court's view Article 12 of the Ankara Agreement and Article 36 of the Additional Protocol were in the nature of an action plan' and were not sufficiently precise, alone or in combination with Article 7 of the Agreement, to be directly effective. As a result, they could not be relied upon by the Demirel couple. In paragraph 24 of the Demirel Case the Court states that

[I]t is not possible to infer from Article 7 of the Agreement a prohibition on the introduction of further restrictions on family reunification. Article 7, which forms part of Title I of the Agreement dealing with the principles of the Association provides in general terms that the contracting parties are to take all appropriate measures, whether general or particular, to ensure fulfilment of the obligations arising from the agreement and that they are to refrain from any measures liable to jeopardize the attainment of the objectives of the agreement. That provision does no more than impose on the contracting parties a general obligation to cooperate in order to achieve the aims of the agreement and it cannot directly confer on individuals rights which are not already vested in them by other provisions of the agreement.

\footnotetext{
${ }^{49}$ Case C-371/08, Judgment of 8 December 2011, Nural Ziebell v. Land Baden-Württemberg, European Court Reports 2011, p. I-00000. Operative part of the judgment. Cf. N. Neuwahl, 'Case C-371/08, Nural Ziebell v. Land Baden-Württemberg', 20 Marmara Journal of European Studies (2012), 165-75.

${ }^{50}$ Case 12/86, Judgment of 30 September 1987, Meryem Demirel v. Stadt Schwäbisch Gmünd, European Court Reports 1987, p. 3719.
} 
One may object that Germany could have been jeopardising the attainment of the objectives of the agreement or undermining the very purpose of the agreement, but this was considered a matter for diplomacy, in other words, as a matter that was not for the court to determine. It is for this reason that the European Court of Justice, in Demirel, refused to evaluate the implications of Article 7 for family reunification. At the time, the question of the conformity with the standstill clauses was not referred to the Court. That question is posed head on in the case currently before the Court and will be examined hereafter, before dealing with the family reunification directive. (See below.)

Whereas it thus becomes clear that a right to family reunification is not laid down in the Ankara Agreement, the fact remains that Article 41(1) of the Additional Protocol does lay down a standstill provision, according to which any regression affecting the rights of private individuals - or companies - to establish themselves in the EU or in Turkey or to provide services is in principle forbidden. Thus, since the situation of EU professionals is similar to that of Turkish professionals, in both cases a new restriction on their family reunification is a setback. From this perspective, the introduction of new restrictions, in those Member States where spouses could freely join at the moment of the entry into force of the Additional protocol, would be a turnaround of the access to economic activity of Turkish nationals, forbidden by Article 41(1) of the Additional Protocol.

\subsubsection{The interpretation of Article 13 of Association Council Decision 1/80}

Article 13 is also a stand-still provision, and it relates to workers more specifically. It provides :

The Member States of the Community and Turkey may not introduce new restrictions on the conditions of access to employment applicable to workers and members of their families legally resident and employed in their respective territories.

The question is again, whether this provision rules out any new provisions requiring spouses to pass a language test before entry into the country. The standstill clause enacted in Article 13 prohibits generally the introduction of any new measure having the object or effect of making the exercise by a Turkish national of the freedom of movement for workers subject to more restrictive conditions than those which applied at the time when Decision No 1/80 entered into force with regard to the Member State concerned. ${ }^{51}$ The standstill provision is

\footnotetext{
${ }^{51}$ Case C-242/06, Judgment of 17 September 2009, Minister voor Vreemdelingenzaken en Integratie v. T. Sahin, European Court Reports 2009, p. I-8465, paragraph 63.
} 
moreover not static. In Toprak, the Court has held that if after the entry into force a relaxation of the rules occurs, any regression is also forbidden. ${ }^{52}$

The provision is to be understood in a wide sense, applying to the situation of all individuals, not only those that are invoking the restriction. The German Federal Social Court ${ }^{53}$, for example, had interpreted the provision as narrow as possible, so that the resulting benefits would relate only to changes which come into force only after the entry of the person concerned to the country. As Gutmann observes, ${ }^{54}$ this interpretation would lead to a difficult and practically almost unsolvable task of having to determine in every single case the actual legal situation that existed at the time of first entry of the person into the country. Consequently, the Court of Justice decided the other way around, namely that the standstill clause had the same legal consequences for all people and that these consequences were not based on the date of the individual's first entry. ${ }^{55}$

Today it is common ground that the stand-still provision grants rights to those Turkish nationals who live in any Member State of the European Union or are admitted to enter a Member State for the purpose of working. The rights are granted not only to active workers, but also people who are not currently employed, but have the intention to take up paid employment in that Member State. ${ }^{56}$ Thus, the provision rules out the introduction of new rules requiring a visa for Turkish workers or making it dependent on the passing of a language test, and the same applies for the introduction of new rules providing for visa conditionality for those family members having a right to employment under Association Council Decision $1 / 80.57$

Where are the limits? In a judgment of $1997^{58}$ concerning Article 7 of the Association Council Decision, the Court of Justice has established that Turkish nationals had not obtained the right to move freely within the European Union, and that the right of family reunification was limited; however, this was before the

\footnotetext{
${ }^{52}$ Joined cases C-300/09 and C-301/09, Judgment of 9 December 2010, Staatssecretaris van Justitie v. F. Toprak (C-300/09) and I. Oguz (C-301/09), European Court Reports 2010, p. I-12845.

${ }^{53}$ Bundessozialgericht, Decision of 11 January 2000 - B 11 AL 29/99 B.

${ }^{54}$ R. Gutmann, 'Döner and the Customs Union, an Unwritten Standstill Clause'. Internet resource at www.ytb.gov.tr/Files/Document/Gutmann-ENG.pdf (last visited 13 January 2014).

55 Joined cases C-317/01 and C-369/01, Judgment of 21 October 2003, Eran Abatay and Others (C317/01) and Nadi Sahin (C-369/01) v. Bundesanstalt für Arbeit, European Court Reports 2003, p. I12301 .

${ }^{56}$ Joined cases C-300/09 and C-301/09, Judgment of 9 December 2010, Staatssecretaris van Justitie v. F. Toprak (C-300/09) and I. Oguz (C-301/09), European Court Reports 2010, p. I-12845.

${ }^{57}$ One may even ask whether such measures can be introduced by the EU, or should be seen as a matter for agreement among all the parties to the Ankara Agreement.

58 Case C-351/95, Judgment of 17 April 1997, Kadiman, European Court Reports 1997, I-2133, paragraph 30 .
} 
adoption of the right to family reunification granted the latter right, and before the long-term resident directive granted circulation rights under certain circumstances. Those rights cannot normally be taken back. Also, the European Court of Justice has subsequently had the opportunity to clarify that a restrictive interpretation of workers' rights is out of the question. According to the ECJ, the standstill clause in Article 13 does not just deal with the conditions of access to employment for the Turkish workers covered by that article, but also with the right of foreign spouses in respect of family reunification. ${ }^{59}$ Commenting on the case-law a European thinktank, the Migration Policy Group, has observed : ${ }^{60}$

[t]he significance of this clarification - paragraph 46 of the ruling - on the part of the ECJ cannot be underestimated. It could very well imply that Turkish nationals should be exempted from the so-called integration test which an increasing number of Member States have introduced for third-country nationals since it could constitute a "new restriction" within the meaning of the standstill clause.

The case-law highlights the fact that the Association Council Decision is definitely furthering the approximation of the EU and Turkey, the latter country having a vocation of membership. ${ }^{61}$ Needless to say, the broad interpretation of rights is in the interest of all parties.

\subsection{The scope of the enabling clause in Art. 7 of the Family Reunification Directive}

The national court had asked about three different legal provisions. On the basis of the foregoing analysis, which focused on the law of the Association Agreement, a good case can be made for ruling out laws or regulations or administrative practices that make immigration of Turkish spouses contingent on the completion of language tests where they did not apply previously. Yet, one may ask, can the Court of Justice avoid having to rule on this matter by considering first the family reunification directive, because that may dispose of the matter? That question is to be answered in the negative for several reasons : whereas the Directive deals more specifically with the type of problem at hand, in case of a conflict between the directive and the Ankara Agreement, the latter would prevail in the relations with Turkish nationals. The European Court of Justice, moreover, rarely questions the need of a national court to get an answer to a question. It is not in the interest of the

\footnotetext{
${ }^{59}$ Joined cases C-300/09 and C-301/09, Judgment of 9 December 2010, Staatssecretaris van Justitie v. F. Toprak (C-300/09) and I. Oguz (C-301/09), European Court Reports 2010, p. I-12845, paragraph 46.

${ }^{60}$ Migration Policy Group, 'ECJ Clarifies Terms Affecting Turkish Workers Residing in the EU', $\mathrm{http} / / / \mathrm{www}$.migrationnewssheet.eu/ecj-clarifies-terms-affecting-turkish-workers-residing-in-the-eu (last visted 13 January 2014).

${ }^{61}$ Cf. M. Maresceau, 'L'accord d'Ankara revisité. Quelques réflexions sur les relations entre 1'Union européenne et la Turquie', in : B. Bonnet (ed.), Turquie et Union Européenne. État des lieux, Bruylant, Bruxelles 2012, pp. 47-77.
} 
Community either, as the two instruments address a different circle of Member States $^{62}$ and are based on different provisions of the TFEU. Finally, it is to be noted that the directive is of interest not only to Turkish families but to all third country nationals and is equally in need of clarification.

The question in this context is, whether this allows a Member State to withhold family reunification if the spouse cannot prove to possess basic level language skills.

\section{Article 7 of the Family Reunification Directive provides:}

Member States may require third country nationals to comply with integration measures, in accordance with national law.

The directive regulates the right of family reunification of third country nationals that legally reside on the territory of a Member State.

Article 3 of the Directive provides:

(1) This Directive shall apply where the sponsor is holding a residence permit issued by a Member State for a period of validity of one year or more who has reasonable prospects of obtaining the right of permanent residence, ${ }^{63}$ if the members of his or her family are third country nationals of whatever status.' $[\ldots]$

The submission of the European Commission's legal service in Imran $^{64}$ departs rightly from the thought that the main aim of the directive is to lay down a right of family reunification for a distinct group of individuals, namely, those who are covered by Article 4(1) of the Directive: 'The Member States shall authorise the entry and residence, pursuant to this Directive and subject to compliance with the conditions laid down in Chapter IV, as well as in Article 16, of the following family members: the sponsor's spouse' [...]. This is confirmed by the ninth recital of the preamble of the directive, which provides: 'Family reunification should apply in any case to members of the nuclear family, that is to say the spouse and the minor

\footnotetext{
${ }^{62}$ As specified in the 17th and 18th recital of the preamble to the directive, in accordance with Articles 1 and 2 of the Protocol on the position of the United Kingdom and Ireland, annexed to the Treaty on European Union and to the Treaty establishing the European Community and without prejudice to Article 4 of the said Protocol these Member States are not participating in the adoption of this Directive and are not bound by or subject to its application. In accordance with Article 1 and 2 of the Protocol on the position of Denmark, annexed to the Treaty on European Union and the Treaty establishing the European Community, Denmark does not take part in the adoption of this Directive, and is not bound by it or subject to its application. The directive may however indirectly be relevant as national law may prohibit a differential treatment of foreigners. However, this is not a matter for the EU to settle, as it does not fall within the scope of EU law.

${ }^{63}$ One may note that the question whether the directive applies to permanent residents was not entertained by the referring court.

${ }^{64} \mathrm{Sj} . \mathrm{g}$ (2011) 540657, in the register of the Court of Justice under $\mathrm{Nr} 873.079$.
} 
children'. In further support of this, the Commission refers to paragraph 60 of the judgment in case C-540/03 (European Parliament v. Council) : ${ }^{65}$

Going beyond those provisions, Article 4(1) of the Directive imposes precise positive obligations, with corresponding clearly defined individual rights, on the Member States, since it requires them, in the cases determined by the Directive, to authorise family reunification of certain members of the sponsor's family, without being left a margin of appreciation.

The Commission acknowledges that even the nuclear family does not have a unlimited right, but points out that when the requirements that are permissible under the directive are met, ${ }^{66}$ the Member States are obliged to accord family reunification. In the action for annulment by the European Parliament the Court of Justice has not mentioned a discretion of Member States in connection with integration measures such as language or integration tests. The only margin of discretion of the Member States which the Court mentions is that of restricting family rights of children over 12 years arriving independently - and even there the Court speaks of a 'partially' maintained margin of discretion: ${ }^{67}$

The final subparagraph of Article 4(1) of the Directive has the effect, in strictly defined circumstances, namely where a child aged over 12 years arrives independently from the rest of the family, of partially preserving the margin of appreciation of the Member States by permitting them, before authorising entry and residence of the child under the Directive, to verify whether he or she meets a condition for integration provided for by the national legislation in force on the date of implementation of the Directive. (NB : Emphasis added by the European Commission).

Apart from this discretion the right of family reunification of the nuclear family is intact, subject of course to the person not being a threat to public policy.

Article 6 of the Directive allows a Member State to reject an application for entry and residence on grounds of public policy, public security or public health. In relation to the fundamental freedoms laid down in primary EU law, the Court of Justice has always interpreted narrowly the discretion of the Member States. As pointed out before, a long line of jurisprudence exists to the effect that Member States, when assessing the public policy derogation, should base their decision on the personal conduct of the individual concerned, and the notion cannot be used as a

\footnotetext{
${ }^{65}$ Case C-540/03, Judgment of 27 June 2006, European Parliament v. Council of the European Union, European Court Reports 2006.p. I-5769, paragraph 60.

${ }^{66}$ Notably, accommodation, sickness insurance and stable income under Article 7(1).

${ }^{67}$ Ibid., paragraph 61.
} 
means of general prevention or deterrence. ${ }^{68}$ This can and should be applied mutatis mutandis to third country nationals posing a threat to public policy.

One may note, furthermore, that the Commission seems to propose a distinction between the existence of a right to family reunification and the possibility for Member States to regulate its exercise for reasons specified in the directive and in accordance with the provisions of the directive. On this account it is clear that a Member State can ask a member of the nuclear family to undergo language training before applying for a visa of entry under Article 7(2). However, it does not follow that the Member State can prevent the exercise of the right to family reunification on the mere grounds that the language training has not resulted in the proof of adequate linguistic skills. ${ }^{69}$ On the contrary, rights granted by EU law to private individuals are matched by positive obligations on the part of the Member States. Support for this position can be found in Vlassopoulou. ${ }^{70}$ Member States cannot just refuse the rights of citizens to become economically active in a Member State on the basis of the fact that they do not fulfil the formal requirements set by law for exercising a particular profession. It is rather the other way round : citizens invoke their rights and the Member States who invoke a derogation are under an obligation to allow the citizen to prove that he or she has equivalent qualifications sufficient to counteract the concerns of the Member State. For a right to be a real right, the candidate must be in a position to make a case why in the particular case the refusal on the mere ground of the non-existence of such evidence is an undue restriction of the right. Not only are the Member State under an obligation to take reasonable measures to enable the person concerned to fulfil the obligation. Also, the person should be able to prove that he or she has equivalent qualities that address the problem at hand. Thus, the Court has held ${ }^{71}$ :

16 Consequently, a Member State which receives a request to admit a person to a profession to which access, under national law, depends upon the possession of a diploma or a professional qualification must take into consideration the diplomas, certificates and other evidence of qualifications which the person concerned has

\footnotetext{
${ }^{68}$ A.o., Case 30/77, Judgment of 27 October 1977, R. v. Pierre Bouchereau, European Court Reports 1977, p. 1999, Case 67/74, Judgment of 26 February 1975, Carmelo Angelo Bonsignore v. Oberstadtdirektor der Stadt Köln, European Court Reports 1975, p. 297.

${ }^{69}$ Interestingly, the matter is regulated to some extent in the long-term residence directive. Member States can require a migrant to attend an integration course for long-term residence, but successful completion cannot be a condition for admission to a second European country as it violates the principle of free movement of persons. This indicates the establishment, in that directive, of a principle of mutual recognition of each other's societies. Cf. Article 15(3) of Council Directive 2003/109/EC of 25 November 2003 concerning the status of third-country nationals who are long-term residents, OJ L 16, 23.1.2004, p. 44-53.

${ }^{70}$ Case C-340/89, Judgment of 7 May 1991, Irene Vlassopoulou v. Ministerium für Justiz, Bundes- und Europaangelegenheiten Baden-Württemberg, European Court Reports 1991, p. I-2357.

${ }^{71}$ Vlassopoulou, paragraph 16 of the judgment.
} 
acquired in order to exercise the same profession in another Member State by making a comparison between the specialized knowledge and abilities certified by those diplomas and the knowledge and qualifications required by the national rules.

17 That examination procedure must enable the authorities of the host Member State to assure themselves, on an objective basis, that the foreign diploma certifies that its holder has knowledge and qualifications which are, if not identical, at least equivalent to those certified by the national diploma. That assessment of the equivalence of the foreign diploma must be carried out exclusively in the light of the level of knowledge and qualifications which its holder can be assumed to possess in the light of that diploma, having regard to the nature and duration of the studies and practical training to which the diploma relates (see the judgment in Case 222/86 UNECTEF v Heylens, cited above, paragraph 13).

18 In the course of that examination, a Member State may, however, take into consideration objective differences relating to both the legal framework of the profession in question in the Member State of origin and to its field of activity. In the case of the profession of lawyer, a Member State may therefore carry out a comparative examination of diplomas, taking account of the differences identified between the national legal systems concerned.

19 If that comparative examination of diplomas results in the finding that the knowledge and qualifications certified by the foreign diploma correspond to those required by the national provisions, the Member State must recognize that diploma as fulfilling the requirements laid down by its national provisions. If, on the other hand, the comparison reveals that the knowledge and qualifications certified by the foreign diploma and those required by the national provisions correspond only partially, the host Member State is entitled to require the person concerned to show that he has acquired the knowledge and qualifications which are lacking.

20 In this regard, the competent national authorities must assess whether the knowledge acquired in the host Member State, either during a course of study or by way of practical experience, is sufficient in order to prove possession of the knowledge which is lacking.

21 If completion of a period of preparation or training for entry into the profession is required by the rules applying in the host Member State, those national authorities must determine whether professional experience acquired in the Member State of origin or in the host Member State may be regarded as satisfying that requirement in full or in part.

There is no reason why this caselaw cannot be transposed to third country nationals, else people are not equal before the law.

This rights-based approach, which takes its queue from both substantive and procedural rights, contrasts with the approach displayed in the past by the Federal 
Administrative Court, in its abovementioned decision of 30 March $2010,{ }^{72}$ which condoned the restrictions and which treated the meaning of Article 7(2) as acte clair, notably for reasons related to the historical context of the adoption of the Directive. ${ }^{73}$ According to the Federal Administrative Court at that time, it was evident from the legislative history of Article 7(2) of the Directive that it authorises Member States to make subsequent immigration contingent on a language requirement. The 'travaux préparatoires' of the directive revealed first of all that the opening clause of the paragraph immediately preceding the enabling clause in the second ('When the application for family reunification is submitted, the Member State concerned may require the person who has submitted to provide evidence...') was not included in either the Commission's original Proposal for a Council Directive of December 1999 (COM doc (1999) 638 final) or the Amended Proposal of May 2002 (COM doc (2002) 225 final). It was added during the deliberations at the insistence of the Netherlands, Germany and Austria (see Council Document 14272/02 of 26 November 2002 p. 13 fn. 2). The Court observes from the Council minutes that the negotiating partners proceeded on the assumption that the opening words covered the demand in the second paragraph for an appropriate knowledge of the language (see Council Document $14272 / 02$ p. $12 \mathrm{fn} .1$ ). ${ }^{74}$ It is further remarked that the European Commission in its report to the European Parliament and to the Council of 8 October 2008 on the application of the Family Reunification Directive, considers the national regulations of Germany, the Netherlands and France requiring the demonstration of language skills before entry as integration measures that are fundamentally permitted under Article 7 (2) of the Directive (COM doc (2008) 610 p. 8 et seq.).

Of course, neither the interpretation of individual institutions or Member States nor the intentions of the drafters of an EU law term has ever been conclusive for the interpretation of any given act of EU law; they are just a criterion used alongside others, such as the literal meaning of the text. This should be considered next. Some of the literature stresses that although the directive allows Member States to make the application of the directive dependent on integration measures, it does not mention integration conditions as a requirement for family reunification (as does for instance the Directive on the status of long-term residents ${ }^{75}$ ). As a European Policy

\footnotetext{
${ }^{72}$ BVerwG 1 C 8.09.

${ }_{74}^{73}$ Ibid, marginal 25.

${ }^{74}$ Moreover, the Court observes that the special provision for the subsequent immigration of dependents of recognized refugees in Article 7 (2) of the Directive is also plainly attributable to the fact that at the time of the negotiations, the Netherlands already had specific plans for the introduction of language tests prior to entry. BVerwG 1 C 8.09 , marginal 26.

${ }_{75}$ Article 15(3) of the Directive provides :

Member States may require third-country nationals to comply with integration measures, in accordance with national law.
} 
Centre report points out, ${ }^{76}$ from a legal viewpoint this is important, because a Member State who is merely allowed to require integration measures is allowed to ask family members to fulfil obligations such as attending language classes; a Member State who is allowed to require the fulfilment of an integration condition before family reunification is granted can effectively prevent family reunification to take place. The Federal Administrative Court did not accept this for the following reasons $^{77}$ :

Although some of the literature argues that the term 'integration measures' is based on a compromise, and - unlike the term 'integration requirements' - allows only certain efforts to be required, such as attending a language or integration course, but not a specific result (see Groenendijk, ZAR 2006, $191<195>$ ), the record of the negotiations on the Family Reunification Directive reveals no such thinking. Council Document No. 7393/1/03 of 14 March 2003, adduced as evidence in this connection, relates to Council Directive 2003/109/EC of 25 November 2003 concerning the status of third-country nationals who are long-term residents (OJ L 16 p. 44) - the Long-Term Residence Directive. Article 5 (5) and Article 15 (3) of the final version of that document do distinguish integration requirements from integration measures. But the precise distinction between the two terms cannot be deduced even from the background materials for the Long-Term Residence Directive. Moreover, although the deliberations on the Long-Term Residence Directive and the Family Reunification Directive did proceed largely in parallel, this circumstance allows only limited conclusions as to the interpretation of the employed terms, since one cannot assume that the different directives on immigration were based on a generalised and sharply distinguished system of terms. For example, the same German term 'Integrationsmaßnahmen' also appears in Article 33 of Council Directive 2004/83/EC of 29 April 2004 on minimum standards for the qualification and status of third country nationals or stateless persons as refugees or as persons who otherwise need international protection and the content of the protection granted (OJ L 304 p. 12) - the 'Qualification Directive'. But it is clear that the term is to be understood differently there than in Article 7 (2) of the Family Reunification Directive, if only from the fact that different terms are used in both the English version ('access to integration facilities') and the French version ('accès aux dispositifs d'intégration').

The literal wording of the enabling clause in Article 7(2) is therefore not conclusive, and for the European Court of Justice it is only one of the criteria to be taken into consideration. As stated before, a (substantive and procedural) rights

This condition shall not apply where the third-country nationals concerned have been required to comply with integration conditions in order to be granted long-term resident status, in accordance with the provisions of Article 5(2).

Without prejudice to the second subparagraph, the persons concerned may be required to attend language courses.

${ }^{76}$ See supra, note 1 .

${ }^{77}$ BVerwG 1 C 8.09, marginal 26. 
based approach is more convincing, also because that corresponds most closely to the objective of the Directive. Accordingly, for those people specified in the directive, there is a right to family reunification, and Member States must make sure that it is a real right.

Last but not least, attention needs to be paid to the fact that the clause 'Member States may require third country nationals to comply with integration measures in accordance with national law' is an enabling clause. In this context one may note that such clauses are becoming more and more common in EU legislation regarding the Area of Freedom, Security and Justice, and one ought not to remain indifferent to the fact that in practice they have the tendency of leading to the undercutting of family rights for immigrants in several Member States. ${ }^{78}$ Without prejudice to the question, whether this clause is an exemption clause (in which case EU law would not apply at all), or a derogation clause, in which general principles of law might be deemed to be applicable, ${ }^{79}$ it is clear that the enabling clause should under no circumstance be interpreted in such a way as implying permission of Member States to violate fundamental human rights such as those laid down in the European Convention on human rights and the EU Charter. Whether that is what is happening in the case at hand needs to be established by the national court in question. ${ }^{80}$

In sum, both EU legislation and the law of the Association Agreement impact on the discretion of Member States in the field under consideration. As regards the Family Reunification Directive, we have seen that it limits the power of the Member States in the field of migration in relation to third country nationals' families more particularly where the sponsor is holding a residence permit issued by a Member State for a period of validity of one year or more and has reasonable prospects of obtaining the right of permanent residence (article 3). To pretend that the national powers are unaffected is to deny that directives are binding as to the

\footnotetext{
${ }^{78}$ A.o., Chr. Joppke, 'Trends in European Immigration Policies', in : J.P. Burgess and S. Gutwirths(eds.), A Threat Against Europe? Security, Migration and Integration, VUBPress, Brussels 2011, pp. 17 - 31, at p. 19.

${ }_{79}^{7}$ See, by analogy, Case C-260/89, Judgment of 18 June 1991, Elleniki Radiophonia Tileorasi AE (ERT) v. Dimotiki Etairia Pliroforissis, European Court Reports 1991, p. I-2925.

${ }^{80}$ In this context there is an argument that the language conditionality is an effective way to combat oppression and forced marriages. Yet, even if it were proven to be true, in order to be a valid excuse the measures would have to be applied evenhandedly to spouses of Germans and foreigners, because one ought to dismiss the idea that Germans should be allowed to commit crimes that others cannot. The directive does not cover this kind of equality: it applies exclusively to foreign spouses of third country nationals. ${ }^{80}$ There is no doubt that the EU Member States are bound to observe the European Convention on the Protection of Human rights and fundamental Freedoms as well as, in areas where it applies, the European Charter of Fundamental Rights. The European Court of Justice will do well to remind the national courts of their obligations in this respect, even if it cannot substitute for them in the application of the law to the individual case.
} 
results which they try to achieve, and that the creation of a right to family reunification is indeed the object of the directive.

The Member States are not allowed to use the disposition of Article 7(2) of the directive as a pretext for automatically refusing the entry of a person who cannot supply the required evidence of language skills. Rather, they are under an obligation to treat the situation on the merits. As language conditionality is not in accordance with the directive, the cases of Ayalti and Dogan highlight how EU law can act as a guarantor of individual rights against indiscriminate use of power by Member State institutions. It is thanks to the availability of judicial avenues that ordinary individuals can contribute to a clarification of the law. Arguably, it is possible that there is no contradiction between the German law and the Directive, because taken literally, the German law in question does not impose the refusal of an entry permit. The German law provides just for a right to a visa based on the existence of proof of adequate language skills. It does not impose the refusal of a visa in the absence of the physical proof. In the way it is formulated, German administrative authorities are able to grant a visa even if the requirement of formal proof of language skills is not given. ${ }^{81}$ But we know now that they may even be under an obligation under EU law to do so.

\section{Evaluation}

Regardless of the invocability of rights in individual cases, language tests and integration tests are thereby not eliminated. Pre-entry tests will remain, and they may in practice discourage movement to those Member States that apply them. Whereas on the macro-economic level this may not have a significant impact on immigration, ${ }^{82}$ on the individual level this may lead to dramas.

As a result, it becomes evident that in the relations between Turkey and the EU the standstill provisions of the Ankara Agreement, its Protocol and Association Council Decision 1/80 have retained all their topicality and importance. Where immigration was not restricted in a Member State on the basis of language tests it cannot subsequently be restricted if it hinders economic freedom - unless it can be defended that the same provisions should be introduced on EU nationals; and this is a proposition that does not sit well with the project of 'ever closer Union'. Whereas enabling clauses such as the one contained in the Directive may lead to a downward trend in the protection of migrants, the Ankara Agreement would protect against such a development. Such references by national courts are a golden opportunity for

\footnotetext{
${ }^{81}$ Section 30 (1) (2) FRA.

${ }^{82}$ E.g., C. Carlitz, 'Language Skills as a Requirement for Family Reunification of Spouses in Germany : Respecting Respect for Family Life ?', in : S. Morano-Foad and M. Malena, Integration for ThirdCountry Nationals in the European Union. The Equality Challenge. Edgar Elgar Publishing, 2012, pp. 303-23, tables at p. 318.
} 
the Court of Justice to reaffirm the purpose of the Agreement and the Association Council Decision.

The European Court of Justice will also be able to carefully point out that Member States in all cases are required to respect human rights. In this regard, it is well possible that third country nationals are better protected under the family reunification directive and the Ankara Agreement than they are under the European Convention of Human Rights. ${ }^{83}$ However, that circumstance does need not be elaborated upon here, and it was not among the questions asked.

\footnotetext{
${ }^{83}$ Statement by the Home Office, Immigration Rules on Family and Private Life (HC194), Grounds of Compatibility with Article 8 of the European Convention on Human Rights. Internet resource at www.ukba.homeoffice.gov.uk/sitecontent/documents/.../echr-fam-mig.pdf last visited 13 January 2014).
} 


\section{References:}

\section{Articles :}

Barbou des Places S., (2012), "La Cour de Justice et l'Accord d'Ankara: variations jurisprudentielles sur la vocation européenne des travailleurs turcs", Bonnet B., (ed.) Turquie et Union Européenne. État des lieux, Bruylant, Bruxelles, pp. 199-228.

Borland S., (2014), "Doctors from the EU to Face Language Tests following Landmark Ruling”, http:/www.dailymail.co.uk/health/article-2076367/Doctors-EU-face-languagetests-following-landmark-ruling.html, Retrieved: 13 January 2014.

Carlitz C., (2012), "Language Skills as a Requirement for Family Reunification of Spouses in Germany : Respecting Respect for Family Life ?’, Morano-Foad S. \& Malena M., Integration for Third-Country Nationals in the European Union. The Equality Challenge. Edgar Elgar Publishing, pp. 303-23.

Gutmann R., (2014), "Döner and the Customs Union, an Unwritten Standstill Clause". www.ytb.gov.tr/Files/Document/Gutmann-ENG.pdf. Retrieved: 13 January 2014.

Hogan-Brun G., Mar-Molinero C. \& Stevenson P., (eds.), (2009), Discourses on Language and Integration: Critical Perspectives on Language Testing Regimes in Europe, John Benjamins, Amsterdam.

Joppke Chr., "Trends in European Immigration Policies", Burgess J.P. \& Gutwirths S. (eds.), (2011), A Threat Against Europe? Security, Migration and Integration, VUBPress, Brussels, pp. 17-31.

Kaddous Chr., "Le rôle de la Cour de Justice dans l'interprétation de l'accord d'Association CEE-Turquie", Bonnet B. (ed.), (2012), Turquie et Union Européenne. État des lieux, Bruylant, Bruxelles, pp. 79-105.

Maresceau M., “L'accord d'Ankara revisité. Quelques réflexions sur les relations entre l'Union européenne et la Turquie", Bonnet B. (ed.), (2012), Turquie et Union Européenne. État des lieux, Bruylant, Bruxelles, pp. 47-77.

Migration Policy Group, 'ECJ Clarifies Terms Affecting Turkish Workers Residing in the EU', http://www.migrationnewssheet.eu/ecj-clarifies-terms-affecting-turkish-workersresiding-in-the-eu (last visted 13 January 2014).

Neuwahl N., (2012), “Case C-371/08, Nural Ziebell v. Land Baden-Württemberg”, Marmara Journal of European Studies, Vol.20, No.2, 165-75.

Pascouau Y., in collaboration with Labayle H., (2011), "Conditions for Family Reunification under Strain - A Comparative Study in Nine EU Member States”. European Policy Centre, pp. 88-94.

Polat V., (2012), "L'accord d'Ankara et la libre prestation des services. De l'effectivité de la clause de standstill”, Bonnet B. (ed.), Turquie et Union Européenne. État des lieux, Bruylant, Bruxelles, pp. 229-242.

Van Oers R., Ersboll E. \& Kostakopoulou D., (2010), A Re-definition of Belonging? Language and Integration Test in Europe. Martinus Nijhoff Publishers.

\section{German law:}

Ausländergesetz, 28 April 1965 (BGBl. I S. 353). 
Aufenthaltsgesetz, 30 July 2004 (BGB1. I S. 1950).

Gesetz über die allgemeine Freizügigkeit von Unionsbürgern, FreizügG/EU vom 30. Juli 2004, BGB1. I S 1950, zuletzt geändert durch Gesetz vom 20. Dezember 2011.

Gesetz über den Aufenthalt, die Erwerbstätigkeit und die Integration von Ausländern im Bundesgebiet (Aufenthaltsgesetz - AufenthG), neugefasst durch Bekanntmachung vom 25. Februar 2008 (BGB1. I S. 162), zuletzt geändert durch Art. 1 und Art. 6 Abs. 2 des Gesetzes vom 1. Juni 2012 (BGB1. I S. 1224).

Gesetz zur Umsetzung aufenthalts- und asylrechtlicher Richtlinien der Europäischen Union vom 19. August 2007 (BGB1. I S. 1970).

\section{EU Law:}

Decision 1/80 of the Association Council of 19 September 1980 on the Development of the Association. Text available at www.inis.gov.ie/en/.../DECISION...1_80.../DECISION_No_1_80_eng.pdf (last visited 13 January 2014.

Council Regulation (EC) No 539/2001 of 15 March 2001, listing the third countries whose nationals must be in possession of visas when crossing the external borders and those whose nationals are exempt from that requirement, OJ L 81, 21.3.2001, p. 1-7.

Council Directive 2003/86/EC of 22 September 2003 on the right to family reunification, OJ L 251, 3.10.2003, p. 12-18.

Council Directive 2003/109/EC of 25 November 2003 concerning the status of third-country nationals who are long-term residents, $O J L$ 16, 23.1.2004, p. 44-53.

Directive 2004/38/EC of the European Parliament and of the Council of 29 April 2004 on the right of citizens of the Union and their family members to move and reside freely within the territory of the Member States amending Regulation (EEC) No 1612/68 and repealing Directives 64/221/EEC, 68/360/EEC, 72/194/EEC, 73/148/EEC, 75/34/EEC, 75/35/EEC, 90/364/EEC, 90/365/EEC and 93/96/EEC (OJ 2004 L 158, p. 77, and corrigenda OJ 2004 L 229, p. 35 and OJ 2005 L 197, p. 34).

\section{German and Dutch case law:}

Bundessozialgericht, Decision of 11 January 2000 - B 11 AL 29/99 B.

Bundesverfassungsgericht, decision of 25 March 2011 - 2 BvR 1413/11 -, NVwZ 2011, 870.

Bundesverwaltungsgericht, judgment of 30 March 2010 - 1 C 8.09 -, BVerwGE 136, 231.

Bundesverwaltungsgericht, judgement of 4 September $2012-10$ C 12.12 .

District Court of The Hague, judgment of 14 February 2011, case 10/6045.

Verwaltugsgericht Berlin, Decision of 25 October 2012, VG 29 K 13812 V.

\section{Case law of the Court of Justice of the European Union:}

Case 67/74, Judgment of 26 February 1975, Carmelo Angelo Bonsignore v.

Oberstadtdirektor der Stadt Köln, European Court Reports 1975, p. 297.

Case 30/77, Judgment of 27 October 1977, R. v. Pierre Bouchereau, European Court Reports 1977, p. 1999, 
Joined cases 286/82 and 26/83, Judgment of 31 January 1984, Graziana Luisi and Giuseppe Carbone v. Ministero del Tesoro, European Court Reports 1984, p. 37.

Case 12/86, Judgment of 30 September 1987, Meryem Demirel v. Stadt Schwäbisch Gmünd, European Court Reports 1987, p. 3719.

Case 186/87, Judgment of 2 February 1989, Ian William Cowan v. Trésor public, European Court Reports 1989, p. 195.

Case 379/87, Judgment of 28 November 1989, Groener v. Minister for Education and City of Dublin Vocational Education Committee, European Court Reports 1989, p. 3967.

Case C-260/89, Judgment of 18 June 1991, Elleniki Radiophonia Tileorasi AE (ERT) v. Dimotiki Etairia Pliroforissis, European Court Reports 1991, p. I-2925.

Case C-340/89, Judgment of 7 May 1991, Irene Vlassopoulou v. Ministerium für Justiz, Bundes- und Europaangelegenheiten Baden-Württemberg, European Court Reports 1991, p. I-2357.

Case C-159/90, Judgment of 4 October 1991, The Society for the Protection of Unborn Children Ireland Ltd v. Stephen Grogan and others, European Court Reports 1991, p. I4685.

Case C-1/97, Birden v. Bremen, European Court Reports 1998, p. I-7747.

Case C-351/95, Judgment of 17 April 1997, Kadiman, European Court Reports 1997, I-2133.

Case C-424/97, Judgment of 4 July 2000, Salomone Haim v. Kassenzahnärztliche Vereinigung Nordrhein, European Court Reports 2000, p. I-5123.

Case C-37/98, Judgment of 11 May 2000, Savaş, European Court Reports 2000, p. I-2927.

Case C-60/00, Judgment of 11 July 2002, Mary Carpenter v. Secretary of State for the Home Department, European Court Reports 2002, p. I-6279.

Joined cases C-317/01 and C-369/01, Judgment of 21 October 2003, Eran Abatay and Others (C-317/01) and Nadi Sahin (C-369/01) v. Bundesanstalt für Arbeit, European Court Reports 2003, p. I-12301.

Case C-275/02, Ayaz v. Land Baden-Württemberg, European Court Reports 2004, p. I-8765.

Case C-540/03, Judgment of 27 June 2006, European Parliament v. Council of the European Union, European Court Reports 2006, p. I-5769.

Case C-228/06, Judgment of 19 February 2009, Soysal and Savatli, European Court Reports 2009 , p. I-1031.

Case C-242/06, Judgment of 17 September 2009, Minister voor Vreemdelingenzaken en Integratie v. T. Sahin, European Court Reports 2009, p. I-8465.

Case C-92/07, Judgment of 29 April 2010, Commission v. The Netherlands, European Court Reports 2010, p. I3683.

Case C-127/08, Judgment of 25 July 2008, Metock and others v. Minister for Justice, Equality and Law Reform, European Court Reports 2008, p. I-6241.

Case C-303/08, Judgment of 22 December 2010, Land Baden-Württemberg v. Metin Bozkurt, European Court Reports 2010, p. I-13445. 
Case C-371/08, Judgment of 8 December 2011, Nural Ziebell v. Land Baden-Württemberg, European Court Reports 2011, p. I-00000.

Joined cases C-300/09 and C-301/09, Judgment of 9 December 2010, Staatssecretaris van Justitie v. F. Toprak (C-300/09) and I. Oguz (C-301/09), European Court Reports 2010, p. I-12845.

Case C-186/10, Judgment of 21 July 2011, Oguz, European Court Reports 2011, p. I-00000.

Case C-221/11, Judgment of 24 September 2013, Leyla Ecem Demirkan v. Federal Republic of Germany, European Court Reports 2013, p. I-00000.

Case C-513/12: Request for a preliminary ruling from the Verwaltungsgericht Berlin (Germany), lodged on 13 November 2012 - Aslihan Nazli Ayalti v. Federal Republic of Germany, Official Journal C63 of 2 March 2013, p. 6-8.

Case C-138/13: Request for a preliminary ruling from the Verwaltungsgericht Berlin (Germany), lodged on 19 March 2013 - Naime Dogan v. Federal Republic of Germany, Official Journal C171 of 15 June 2013, p. 14-5. 